\title{
Study on Optimal Design of University Campus Landscape on the Basis of Educational Function
}

\author{
Li Yan \\ Huanghe Science and Technology College \\ Zhengzhou, China
}

\begin{abstract}
Beautiful and pleasant campus landscape is a silent classroom, which can guide teachers and students to form positive attitude towards life. In order to meet the requirements of diversified communication between teachers and students under the diversified social background of multiple values, it has vital practical significance to optimize and design the campus landscape environment from the perspective of education function. This article combines the current actual situation of the construction of campus landscape, putting forward the measures of university campus landscape design optimization on the basis of educational goals, cultural goals, ecological goals, social goals and economical goals in order to reasonably use them according to the specific situation of the schools in campus landscape design and create campus landscape environment where the educational function can be given full play.
\end{abstract}

Keywords-educational function; university campus; landscape optimization; design strategy

\section{THE GOALS OF OPTIMAL DESIGN OF UNIVERSITY CAMPUS LANDSCAPE}

\section{A. Educational Goals}

The goal of higher education is through infusion, influence and guidance of education for subject of education to promote them to absorb and understand the cultural knowledge and then inherit and innovate culture. It urges the educated to know the world constantly and come to a unification of socialization, integration and popularization then become well-rounded talents in the new period. With the development of socialization, integration and popularization of higher education, the materials of education also become more extensive and they are not limited to books and classrooms. The campus environment that students live their daily life is the materials of education as well. Based on this, it is necessary to optimize it starting from the essential requirements of education to meet the target needs of higher education. Optimal design of university campus landscape from the direction of university education goals can promote the harmonious and sustainable development of university to some extent.

\section{B. Cultural Goals}

University culture is the root and soul of college survival and development and an important scale to measure the operational level of a school and an important assurance for a school to achieve sustainable development. With the continuous development of college operational level, in campus, colleges only pay attention to the improvement of buildings and related supporting facilities and ignore the construction, development and inheritance of university culture. University is a significant position for the accumulation, spread and innovation of culture and a cultural exchange station. As one of the material carriers of campus culture, national culture and regional culture, campus landscape should undertake the important responsibilities of cultural construction and inheritance. Each school and each region have different culture. The campus landscapes especially the construction of campus culture landscape need to regard the campus culture and regional culture as themes to increase the personality and value of campus landscape. According to the phenomenon of deficiency of current campus culture, the campus landscape needs to be optimized from the cultural perspective to let the campus culture and campus landscape blend.

\section{Ecological Goals}

University campus is the spatial place for the learning and living of teachers and students. The ecological goals that the campus landscape construction needs to pursue are the ecologicalization of campus landscape plants, campus landscape materials and the campus planning design concept. When the campus landscape has the above three ecological traits, the campus landscape environment naturally become the ideal habitat. The ecologicalization of plants landscape need to ensure the rich species and various shapes of campus plants, and the plant configuration is reasonable, using plants to beautify and decorate the campus environment to ensure the balance and stability of campus ecosystem and reach the coordination of artificial environment and natural environment. The ecologicalization of campus landscape materials mainly refers to that the materials (paving materials, building materials, etc.) used by landscape construction consider too much about the requirements of low carbon, no pollution and sustainable development, etc. The ecologicalization of campus planning design concept refers to that campus planning and landscape design reasonably adopt circulation concept, ecological restoration concept and low carbon concept to make university campus become harmonious ecological campus from macro perspectives. To sum up, the ecological goal of campus environment landscape design is making great efforts to make the campus 
become a integral campus ecosystem that uses gardens to protect ecology, uses ecology to show humanism and uses humanism to promote development.

\section{Social Goals}

With the increasing development of opening, socialization and popularization of colleges, and the diversified development of professional education, scientific research and social services, university campus is no longer a closed ivory tower. The communication between colleges and society, universities is increasingly frequent. Therefore, it may exist that the university culture loses essential things in the wave of opening and socialization. The phenomenon of similar culture appeared between schools and schools is not only the question that schools lose characteristics, but also in relation to the development of school and the inheritance of culture. Based on this, strengthening the construction of university culture, consolidating and maintaining the vigor and vitality of university spiritual culture are important measures in the process of campus development. Because of the increasing exchange opportunities between colleges and society, if campus culture want to keep their own characteristics, it is necessary to strengthen the unique spiritual culture of each university. Campus landscape as the second classroom for teachers and students to learn and live, the quality of landscape has profound influence on minds and bodies. In addition, university campus landscape is a good carrier to annotate culture, express culture and strengthen culture. So the social goals of campus landscape optimization are reflecting the characteristics of schools, keeping the nature that schools as pure land of academic, making universities still have distinctive characteristics in the process of opening and socialization and always be the ideal garden for study and scholarly research.

\section{E. Economical Goals}

Nowadays, the constructions of economical society, low carbon society have become a consensus. University has always been as the original place of advanced thoughts and advanced culture, it has obligatory responsibilities of the times and social responsibilities. And the implementing of low carbon and environmental protection concept should start from colleges. Colleges should make full use of its own advantages, strongly advocate and practice the concept of low carbon economy in and out of campus and make efforts to make university campuses become model windows of low carbon and environmental protection concept. It not only needs to give full play to the resource advantages of intellectual talents in colleges, widely propagandize the low carbon concept, popularize the scientific knowledge of low carbon, build an atmosphere of constructing conservationoriented campus, but also needs to put the related ideas of low carbon environmental protection and ecological conservation into practice in campus landscape. Based on these economical goals, it needs to moderately optimize the campus landscape, make every effort to efficiently use the campus space resources, reduce related costs of planning and construction of campus landscape and the maintenance charges in the process of campus operation, implement the principle of reducing raw materials, reusing and recycling, strive to build a resource-saving, environment friendly and low carbon environmental protection university campus of sustainable development. It is not only the requirements of campus landscape construction, but also effective method to educate and edify teachers and students.

\section{OPTIMIZATION DESIGN STRATEGY OF UNIVERSITY CAMPUS LANDSCAPE ON THE BASIS OF EDUCATIONAL FUNCTION}

\section{A. Inheriting the Traditional Historical Culture, Constructing the Campus Aesthetic Space of Rich Connotation}

University campus landscape not only has using function, with the development of history, some campus gradually generates deep spiritual value. Campus is just like a real object teaching material which has a silent transforming influence on teachers and students, making students learn knowledge at the same time feel strong atmosphere of humanism and regional culture information. The contemporary university campus landscape should not only pursue the function of campus space, but also pursue the quality of space, and create campus aesthetic space with humanity meaning. Facing the problems of non fusion of new and old, disunity of styles of campus landscape in the process of expansion and reconstruction of old campus, and the phenomenon of cultural dislocation appearing in the process of different construction of new campus, we should strive to actively transfer the different historical and cultural spirit of each university in the university campus landscape design to strengthen the connotation of campus landscape and the value of campus aesthetic space, achieve enlightenment education, environmental education, use the campus landscape of beautiful scenery and profound culture to edify and educate teachers and students to cultivate their tastes and edify them quietly. However, in the practice of campus landscape construction, it is not a very easy thing to inherit history, mapping culture and extrude education and we should try from the following aspects:

1) Planning design of campus landscape should be personalization and characterization. While inheriting the tradition, it should reflect spirit of the time;

2) Campus landscape should focus on the construction of campus culture landscape, practically infuse varied culture elements such as campus culture, regional culture and discipline characteristic culture into landscape entity, making campus landscape "the teaching materialization";

3) For the excellent design methods and ideas proved by practice, we should selectively learn and absorb according to the actual situation of the school itself.

Not imitate each other but actively use for reference, not copy and apply mechanically but boldly absorb, we should strive to build campus landscape environment which has rich potential educational function. Only this can we ensure that campus landscape meets the requirements of campus as a large outdoor classroom. It is helpful for the development of school and the promotion of comprehensive strength. 
Because of the different current situations of between the new and the old campus, the specific strategies to inherit the historical culture also have certain differences. In general, for old campus, we need to pay attention to carry out protection and development simultaneously, protect historical cultural relics and remains and carry forward the historical humanities spirit, at the same time we also need to actively advocating the modern university educational philosophy which keeps pace with the times; for new campus, we need to take the landscape construction strategy which combines macro with micro, mainly pay attention to the integration and improvement of cultural environment. Besides, we should not only work on the concept of planning and design, but also fully excavate and reflect the campus history culture on the detail design of campus landscape, educate people by environment in essence and better implement the value of campus landscape.

\section{B. Continuing University Spirit and Promoting the Implicit Value of Campus Landscape}

Because the aspects such as the purpose of running a school, development history, school-running patterns and environment of running schools of every college are different, the cultural spirit of every school is different, which is an important symbol of difference between universities. It is also university spirit, which is the concentrated expression of sentiment, behavior, value and ideal and faith of all the teachers and students. Because college days is an important period to form view of life values, high quality campus space environment has active influence on shaping the ideas of college students. Therefore, actively promoting and interpreting university spirit is vital to improve the implicit values of campus landscape, strengthen the educational influence that campus landscape has on young students. University spirit often reflects in the historic culture of campus, reflecting through school spirit, school motto and theory on school management of the school. Meanwhile, university spirit also contains in cultural landscape such as historical sites and buildings in schools. The most important point that we optimize the university campus landscape is to continue university spirit, combine university spirit with campus landscape construction, shape special campus landscape which not only has obvious historical culture traces but also conform to the requirements of the times. For example: skillfully combine the pearls of wisdom and life story of famous alumni with campus landscape, educate students how to behave, handle affairs and engage in scholarship; combine school badge, school motto with landscape to complete the embodiment of campus education thoughts and education values; we can also extrude the spirit of the school through the school's history, run through campus scenery spots and school spirit to complete the extension of university spirit. But when continue university spirit and design campus landscape, we should not blindly inherit the history, but combine the actual situation of the school with innovation and development. And it also reflects the university spirit characteristics of keeping pace with the times and broad inclusiveness.

\section{Creating a Multi-Level Communication Space and Meeting the Diverse Communication Requirements}

There is no direct relationship between the construction of communication space and the realization of the educational function of campus landscape, but high quality campus communication space provides a good place for various communication activities in campus, makes it convenient for carrying out of activities such as academic exchange, extracurricular practice, extracurricular teaching, outdoor exercise, recreation and sightseeing. The contemporary college students present diversity and randomness and various forms of communication space with rich gradation meet the requirements of different types of users. For this perspective, campus landscape environment better realizes the function for education service.

In order to achieve the goal of building variety space, we can take the following effective measures:

- Because the curriculum provision of modern university is flexible and diverse and the school hours of different departments and different majors are different, students have more flexible and disposable time. In order to answer the multi levels of campus interaction activities and the diversity of available time, the space types should be as rich as possible to meet requirements of different levels. Campus space should pay attention to the transition and cohesion from wide open space, half open space and private space, at the same time, pay attention to the dispose of gray space closing to architectural interface, at last build a three-dimensional multi-level higher participatory communication space;

- In order to coordinate the diversity that every place holds activity content, the communication space atmosphere should be harmonious with the types of activities as far as possible. For example, learning communication space should be quiet and rigorous; activity space should be enthusiastic and relaxed; leisure viewing space should be comfortable and natural to provide all kinds of comfortable environments for teachers and students.

In the meantime, we should moderately mix the campus intercourse space, which can stimulate the vitality of campus space. When various activities in campus are in their proper place, all users of landscape can take what they need and truly play proper values and interweave space, the communicative activities in campus will be rich and colorful. These activities constantly bring forth new possibilities on the time, and then the charm of campus also grows. The distinctive campus intercourse space with rich gradation integrates the concept of modern higher education into the whole university campus. Therefore, creating a multi-level communication space and meeting the demand of diversification are the foundation and precondition for campus landscape to fully realize the education function. 
D. Improving the Imaginability of Campus Landscape and Strengthening the Space Sense of Belonging of Teachers and Students

The sense of belonging teachers and students have on campus landscape space derives from the humanization design of campus landscape and the imaginability of campus space. It demands when construct campus landscape, we must pay close attention to place spirit and the identifiability of campus landscape. Because the speed and scale of current university campus construction arises an unprecedented boom, campus space appears too spacious and lacks of popularity because of the large scale. University teachers and students will lack space identity and sense of belonging. University campus like a small city because of the complete function, the construction of campus landscape space should create places to carry all kinds of activities and ensure that campus space has attractive elements. Only this can keep the popularity and vitality of space. In consequence, it has vital practical significance to introduce the place spirit to the construction of campus landscape. The space spirit can well arouse the sense of identity of teachers and students to campus landscape, make them feel pleasure to learn, live, contact, step forward in campus landscape environment, be unconsciously influenced by the edification of knowledge and increase the sense of belonging of campus space. At the same time, we need to increase the identification of campus landscape space and make the users of campus landscape have a good interactive relationship with campus landscape to increase the sense of identity and belonging of space, which need us to base on the city image theory of Kevin Lynch to reasonably design the campus landscape, tease the structure of campus space and ensure the accessibility and utilization of campus space.

\section{CONCLUSION}

The current society is the age of knowledge explosion. The fast updating speed of all kinds of information makes people too busy to attend to all. University is the cultural hall with colorful knowledge and its main function is to accomplish the important task of imparting knowledge, spreading civilization and inheriting culture. In order to make the knowledge communication in the campus more efficiency, campus landscape as the material environment of campus needs to have reasonable function division and make each functional area in its proper place, furthest realize the value of each partition in campus and serve teaching activities better. Campus functional partition such as the teaching district of scientific research, students' living area, sports activities area and leisure landscape areas should be planned reasonably. Not only making the function reasonable, but also using the campus space furthest. Only like this, each partition can contact better and together service the overall situation of the school teaching. However, each functional area in campus has different status in campus and we need to distinguish the primary and secondary and moderately intensify teaching district of scientific research, students' living area and leisure landscape area, reasonably weaken the staff living area and rear services area. Meanwhile, we need to plan and design the campus functional groups and axis with density interaction and flexible degree, build the core landscape areas inside the campus, use landscape axis to connect the landscape stages in campus to make the structure of campus landscape space more distinct for teachers and students to identify. In conclusion, combing place spirit with city image theory to optimize the campus landscape will be helpful for campus landscape to become more attractive. It is of great help to increase the space identity and sense of belonging of campus landscape users and it is also the inner requirement to play the function of "educating people by environment" of campus landscape.

\section{REFERENCES}

[1] He Jingtang. Several Development Tendency of the Current College Planning and Construction [J]. New Building, 2002.

[2] Zhou Yihu, Song Zefang. Higher School Building. Planning and Environmental Design [M]. Beijing: China Building Industry Press, 1994.

[3] Gao Jisheng. The Point Tips of the Campus Planning of Contemporary College [J]. New Building 2002. 